DOI 10.37882/2500-3682.2021.02.09

\title{
ЗООМОРФНЫЕ ИПОСТАСИ ЗЕМЛИ В ФОЛЬКЛОРЕ СЕВЕРНЫХ НАРОДОВ
}

\section{ZOOMORPHIC HYPOSTASES OF THE EARTH IN THE FOLKLORE OF THE NORTHERN PEOPLES}

\section{Kashlatova}

Summary: The oldest layer of Ugric mythology is saturated with evidence of the existence of ideas about the organic relationship between man and animal, the leading role of the female principle in the creation of Nature. One of the Oldest Mothers of nature is mother Earth, represented in zoomorphic form. Folklore materials of the Ob Ugrians indicate that the earth itself was thought of as a living being and was identified in the ideas about it with images of animals. The purpose of this article is to introduce readers to the ancient ideas of the $0 \mathrm{~b}$ Ugrians.

The materials of the study were folklore texts published in various collections, historical sources of famous Russian and foreign ethnographers. The research materials can be useful for folklorists, ethnographers, historians, religious scholars and students studying the language and culture of the Ob-Ugric peoples, and can also be used in the preparation of theoretical materials on the history and culture of the peoples of Western Siberia.

Keywords: Mother of nature, Great mother, zoomorphic appearance, elk, bear, Kattas-Imi.
Кашлатова Любовь Васильевна

К.культурологии, БУ «Обско-угорский институт прикладных исследований и разработок», пгт. Берёзово kashlatovalv@mail.ru

Аннотация: Древнейший пласт угорской мифологии насыщен свидетельствами существования представлений об органичной взаимосвязи человека и животного, ведущей роли женского начала в процессе творения Природы. Одна из древнейших Матерей Природы - это Мать Земля, представленная в зооморфном облике. Фольклорные материалы обских угров указывают, что сама земля мыслилась живым существом и отождествлялась в представлениях о ней с образами животных. Целью данной статьи является познакомить читателей с древними представлениями обских угров.

Материалами исследования послужили фольклорные тексты, опубликованные в разных сборниках, исторические источники известных российских и зарубежных этнографов. Материалы исследования могут быть полезны фольклористам, этнографам, историкам, религиоведам и студентам, изучающих язык и культуру обско-угорских народов, а также могут быть использованы при подготовке теоретических материалов по истории и культуре народов Западной Сибири.

Ключевые слова: Мать Природы, Великая Мать, зооморфный облик, культ лося, медведя, Каттась-Ими.
Все традиционное миропонимание северных народов пронизывает идея последовательного рождения того или иного класса предметов, существ или явлений определенной матерью. В качестве основных рождающих начал можно назвать Землю-мать, которая осмыслялась как прародительницей, всего, что есть на земле. Ханты в своих мифологических представлениях внешнего мира таинственную вселенную изображали доступно и просто, как картину жизни людей. Сама вселенная мыслилась живым существом и отождествлялась в представлениях о ней с образами животных.

Многие сибирские народы представляют, что Земля рождала самостоятельно, без участия мужского начала. Она представлялась наиболее близкой людям: «Мы сидим на голове Моу-нямы». Иногда Земля-мать выступает как лосиха или олениха, на спине которой живут нганасаны [4, 21].

Люди представляли Землю телом громадного зверя, где реки - это вены, озера - глаза, деревья - шерсть $[3,260]$. Ханты Землю представляли живой, поэтому ей нельзя было наносить раны, тыкать острым предметом.
«Земля - живое существо», - говорят саами. - Деревья и травы - её волосы. Зеленый дёрн, тундровые мхи - её кожа. Нельзя делать больно Земле, нельзя её ранить...» $[26,18]$. По мнению Т.А. Молдановой «В настоящее время символ Земли-Матери всё ещё обладает жизненностью и мощной силой воздействия, а нефтяное освоение территории проживания хантов формирует у них образ Земли как женщины с искалеченным лицом» [15, 269, 271].

В фольклоре её эпитеты: «кожистая земля, волосатая земля» $[13,15 ; 19,34-35 ; 3,260]$, это означает, что она (земля) приобрела покров в виде растительности, покрылась «кожей» (мхом, травой) и «волосами» (лесом). В верованиях манси есть женское божество и называют её Калтась Сянь, где Сянь - это 'Мать'. Иногда в обращении к богине употребляют выражение пунынг Сянь 'шерстистая Мать' это говорит о древности её происхождения $[20,26]$. Один из её эпитетов «черная Земля-мать, шубная Земля-мать, пушная Земля-мать» связан с названием Земли $[18,586]$. Ханты усть-казымского Приобья богиню Калтащ называют Мать-земля, поэтому «детям нельзя копаться в земле и тыкать железными предметами, чтобы не причинить земле боль». Они считают, что Калтащ 
символизирует всё, что рождается на земле, «она нас кормит» $[22,41]$.

Связанная с землей, Богиня-мать дает жизнь не только людям, но и зверям, птицам. Б. Мункачи весь ряд женских образов считал возможным называть одним термином - Мать-земля. Он считал, что «первой стадией существования образа было осмысление как земля со своими её свойствами [34, 71-72]. Образ Земли, прежде всего, вмещает в себя такие идеи, как жизненная энергия, плодовитость и изобилие, мудрость женского естества. Тайна женского полового созревания - во власти Земли-Матери и скрыта в ней. Девушек во время первых месячных укладывали на травяной покров для того, чтобы впитать в себя плодоносящую силу Земли [15, 268269].

Ряд советских этнографов полагают, что наиболее архаичными в мировоззрении современных коренных народов Сибири являются представления о Матерях Природы, восходящих первоначально к единой Великой Матери; Г.Н. Грачева [4], Н.Б. Хлобыстана [30], Сагалаев [24], Напольских [17] и др. Именно в этот период археологи находят многочисленные женские статуэтки [30, 10, 69]. Г.Н. Грачева провела исследование традиционного мировоззрения охотников Таймыра и считает, что «самой главной все-таки считалась Земля-Мать. Она как будто родит всё живое и без вмешательства Солнца и Луны, но, тем не менее, делит с ними свои функции» $[4,25]$.

Особая заслуга в изучении религии и традиционного мировоззрения народов Западной Сибири принадлежит К.Ф. Карьялайнену, опубликовавшему три тома в 1921, 1922, 1927 гг., на русском языке они были выпущены в 1994-1996 гг. в переводе Н.В. Лукиной. Для К.Ф. Карьялайнена было особенно ценным то, что вогулы (манси) и остяки (ханты) смогли сохранить в своих обрядах и обычаях наследие ранних ступеней развития, которое у других народов почти исчезло [7, 15].

С 1990-х годов научными исследованиями в области духовной культуры стали заниматься сами представители национальной интеллигенции, выходцы из традиционной среды, к числу которых относится и автор. В науке появились сведения о локальных особенностях отдельных групп хантов и манси в работах Е.А. Ромбандеевой, Т.А. Молданова, Т.А. Молдановой, М.А. Лапиной, С.А. Поповой, Т.Р. Пятниковой и др.

В основу данной статьи легли фольклорные материалы, отражающие традиционное мировоззрение обских угров, касающиеся нашей темы. Древнейший пласт угорской мифологии насыщен свидетельствами существования представлений об органичной взаимосвязи человека и природы, ведущей роли женского начала.
Несмотря на то, что к настоящему времени накоплен значительный материал о различных сторонах традиционных представлений обских угров (В.Н. Чернецов, Н.В. Лукина, В.М. Кулемзин, Е.П. Мартынова, А.М. Зенько, В.В. Напольских, Е.А. Шмидт и др.), остается ещё немало вопросов в области изучения древних взглядов о происхождении женских божеств. В этнографических исследованиях мировоззренческий образ женщины трактуется, прежде всего, как образ Матери Природы, богини-матери, подательницы жизни. Данная статья является продолжением исследований автора по женским божествам в культуре обских угров. Необходимость исследования женских божеств в первую очередь обусловлена тем, что в представлениях многих народов, в том числе и народа ханты, в руках богинь находятся рождение, жизнь и смерть людей.

Одна из древнейших Матерей Природы - это Мать Земля, представленная в зооморфном облике. В хантыйском фольклоре есть эпитеты сухынг мув ангки, пунынг мув ангки 'в одеянии земля-мать, в шерсти земля-мать', которые подтверждают данное высказывание, что ранее в устной традиции народа ханты Земля олицетворялась в зооморфном облике. По представлениям хантов, Земля представляется в образе Лосихи, «изначальная ипостась Земли - Лосиха» $[15,238-240,269]$.

Поскольку и лось, и дикий северный олень являются главными объектами охоты, приносят людям еду, тепло, то именно они составляют основу идеи спасения жизни в экстремальных условиях Заполярья и тайги. Данный образ зафиксирован у многих народов Севера: у эвенков - хозяйка мира имела вид огромной лосихи или самки дикого оленя. У орочей в образе изначальной гигантской восьминогой лосихи выступает Земля. Землю орочи называют «Спинной хребет Земли» или дословно «Спинной хребет лосихи» $[33,63]$. Символ Лося (Лосихи), олицетворяющий архетип Матери, изначально воплощает в себе такие понятия, как изобилие, плодородие, женскую воспроизводящую силу [15, 268-269].

Лось занимал центральное место в производственном культе древних охотников, в тех верованиях и обрядах, которые были связаны с самой основой существования. У многих народов Севера и Сибири есть представление о космическом лосе. Всем известен хантыйский миф о шестиногом лосе «О млечном пути на небе» $[13,68,297]$. В данном мифе, говорится о том, что лось был таким быстроногим, что его не могли догнать люди. Чтобы люди могли охотиться на него, сын Торыма догнал его и отрубил у него две задние ноги [11, 41]. У эвенков бассейна Подкаменной Тунгуски есть сказание о смене дня и ночи, где рассказывается об охоте на Лосиху с Лосенком. Каждую ночь они выходят на пастбище, и становятся видимыми людям - космическая лосиха Хонглэн отождествляется с созвездием Большая Медве- 
дица и Лосёнок - это Малая Медведица [30, 72]. В некоторых текстах объединены сюжеты о происхождении звезд и экзогамных объединений Пор - Мось. Медведица с медвежатами, родившая первую женщину Пор или Мось, - это три звезды на небе [13, 227-232, 232-233] либо, по другому варианту, созвездие из семи звезд Малая Медведица. Представления о небесных лосихах свойственны многим охотничьим народам, у которых существуют мифы о двух небесных владычицах мира, наполовину женщинах, наполовину лосихах, от которых зависит всё благополучие охотничьих племен [23, 81].

Значение лося в жизни и мировоззрении хантов было чрезвычайно велико. В прошлом у хантов повсеместно был распространен лосиный праздник по случаю его добычи. В настоящее время такой праздник перестал существовать. По мнению С.А. Поповой, «праздники и обряды в честь женских духов-хозяев леса, воды, гор были широко распространены в древности, через них прошли потомки манси как через одну из ступеней развития религиозных представлений, представлений о мироздании, круговороте жизни, установлении норм и обычаев» $[21,41]$. Отзвуком архаичных воззрений является то, что в настоящее время при охоте на этого зверя, разделывании туши, приготовлении блюд из мяса лося до сих пор соблюдаются строгие правила, связанные с табуированием древнего животного [10, 167; 28, 45]. В том месте, где добыли лося, обычай требовал устраивать обряд жертвоприношений небесному богу, так как он имел небесное происхождение. Целый ряд обрядовых действий был направлен на то, чтобы обеспечить возвращение поедаемого зверя в прежнее состояние. Нельзя было небрежно обращаться с костями, опаливать губы, железным ножом перерезать сухожилия, скармливать мясо собакам. Поедание лосиного носа предвещало охотникам удачную охоту на этого зверя. Следы культа лося по сей день наблюдаются у хантов [8, 22-24; 9, 86-88, 101; $6,196 ; 28,44-45]$.

Равное положение с культом лося занимал медведь. Культ медведя ученые находят у многих народов, своими корнями он уходит в глубину веков. Сибирские народы видели в могучем звере, хозяине тайги первопредка, культурного героя. Почитание медведя, предка и культурного героя имеет долгую историю, отражено во многих мифах и ритуальных традициях. Медвежий праздник по случаю добычи зверя и ритуальная забота о черепе и костях медведя имела самое широкое распространение по всему Северному полушарию. Существование медвежьего праздника отмечено в Европе у древних карелов, финнов и саамов; в Азии - у ханты, манси, ненцев, алтайцев, кетов, тувинцев, эвенков, эвенов, якутов, юкагиров и т.д. $[25,418]$.

В традиционной культуре хантов медведь занимает центральное место. Он относится к священным живот- ным, приходится сыном Нуми Торыма, имеет небесное происхождение, поэтому не принято было называть медведя на прямую, у него было табуированные названия Нюрым вой 'болотный зверь', Ошни ойка 'зверь в шубе', пупи 'божество, дух', куншынг ойка 'когтистый зверь' Торым эви 'Дочь бога'. «Медведь раньше человеком был. Он понимает человеческий язык. Он самый младший у нас, у людей» рассказывает информант-селькупка $[30,112]$.

Ханты и манси по случаю его добычи устраивают праздник, смысл которого заключается в стремлении помирить душу медведя с добывшим его охотником. Таким образом, самые древние локальные периодические Медвежьи танцы посвящались «хозяйке леса», где говорится, что первой на Земле появляется медведица [21, 31]. В «Медвежьей песне о спуске с неба» поется: «Жадный зверь могучий, моя доченька, Мною сказанные слова не послушала.

- Батюшка, на землю отпустил бы ты меня!

- Ну, как хочешь, доченька, если сильно так захотелось, спущу тебя я на землю» [13, 303-304].

Отзвуком небесного происхождения медведицы является обряд разделывания туши добытого медведя охотниками «Коль медведица я, то четыре завязки развязывают» [3, 114]. Шкуру со зверя снимают так, как будто развязывают четыре-пять завязок женской шубы cax $[16,99 ; 20,39]$. Традиционная мужская одежда ханты - малица, она глухая и не имеет застежек, а женская одежда распашная, имеет разрез спереди и полы шубы соединяются завязками $[13,509 ; 29,127,174 ; 12,71]$.

В фольклорных текстах мы находим: «вносят меня в дом... На широкий стол из трех досок, на широкий стол из четырех досок, сажусь я, как лесная женщина, как горная женщина» $[14,148)$.]. С.А. Поповой сообщает, что суть праздника не в том, кто его добыл и какого пола зверь, а в роли женщины в древнем обществе как хозяйки, главы большой семьи, разные поколения которых проживают в отдельных углах одного жилища. Появившись на Земле, как первая женщина и первая Мать, она организует миропорядок, устанавливает нормы поведения, систему ценностей, то есть всё, что мы называем традиционным мышлением, мировоззрением, религией [21, 34]. В мансийской мифологии обозначена целая эпоха, когда женщина была социально активнее мужчины - со времени рождения первого ребенка-человека первой Матерью «старухой» от первого мужчины «старика» до времени, когда её дети, а затем и внуки разошлись по разным территориям и стали там хозяевами» [10, 32-34].

В хантыйском мифе «О сотворении земли» именно женщина творит растительность, животных «много черного зверя стало бегать, много красного зверя стало бегать». Затем позволяет охотникам убивать их. 
На медвежьем празднике песни о медведе считаются священными, их ещё называют вой ар 'звериные песни'. В них поется о происхождении медведя, о спуске его с неба и поднятии вверх. Согласно одной из трех версий, медведица (медведь) приходится дочерью (или сыном) Верховного бога Нуми-Торыма, который воспитывает её (его) в «задней комнате своего дома», в меховом гнезде. В священной песне от имени медведицы поется, как «Золотой Карыс-Батюшка, Золотой Карыс-Отеи, (меня) возмужалого сильного зверя на человеческую обжитую слоистую Землю спустил (с небес)» $[2,249]$. В другом варианте медведица рожает женщину Пор, то есть выступает в качестве прародительницы фратрии. Данный миф, по мнению исследователя, является самым древним, в сказке «Маленькая женщина Мось» появление медведицы «воспринимается как само собой разумеющегося» [32, 7-9]. На Казыме записан отрывок из медвежьей песни, в котором говорится о том, как он был сыном женщины, но за ослушание был наказан и, обидевшись, ушел в лес, там поздней осенью он стал замерзать, после чего обрел иной образ, сделавшись медведем. Многократно он выходил к поселку, чтобы подкараулить мать и отомстить ей, но каждый раз находил причину этого не делать $[9,165]$. На Вахе медведя помещали в почетный передний угол со словами: «Здравствуй, лесной старик». Затем происходил обряд гадания, при котором устанавливалось, кем из умерших родственников он является. Ваховские ханты считали, что человек после смерти превращался в медведя [10, 170]. Если в архаическое время медведица (медведь) называлась «хозяйкой леса», то со сменой родового строя, с насаждением духов в мужском обличии медведь (медведица) считается «хозяином тайги».

В.Н. Чернецов, занимаясь исследованием фратриального устройства у обских угров, замечает: «Интересно отметить, что предком фратрии (пор) является, следова- тельно, не медведь, а медведица, что более согласуется с нормами материнского рода. Очевидно, что медведем она была замещена в последующее время» $[31,27]$.

Таким образом, рассмотренные выше мифологические персонажи и религиозные воззрения северных народов дают представления о Великой Матери Природы - Земле-матери. Земля многолика - она предстает в различных зооморфных образах: как в сверхъестественных (фантастических) существах, так и в зверином - реально существующие представители животного мира (лось, медведь), которые рассматривались в данном исследовании. Архетип богини-матери, Земли-матери, Великой матери в мифологии никогда не концентрируется на каком-то одном образе. Чем к более древней эпохе мы обратимся, по мнению Ю.В. Балакина, тем более «монолитным» следует ожидать явление этого архетипа, с ходом времени, неизбежно подвергающегося дроблению и стратификации $[1,213]$. Древнейший пласт угорской мифологии насыщен свидетельствами существования представлений об органичной взаимосвязи человека и природы, ведущей роли женского начала. В одном лице совмещать черты Матери-земли, жизнеподательницы и фратриального предка - результат естественного развития древнейших представлений о значение материнского начала. Во времена первотворений женщина взяла на себя жизнетворящую роль.

Образ Земли в ипостаси лосихи является самым ранним этапом в эволюции женского божества. Выше мы упоминали о том, что первооснову образа медведя составляли древнейшие архетипы матери и мудрой старухи, впоследствии вытесненные мужскими архетипами отца и мудрого старика. Необходимо подчеркнуть, что в проведённом исследовании в результате предпринятой реконструкции далеко не охватывает всего многообразия деталей и вариаций зооморфных ипостасях облика Земли.

\section{ЛИТЕРАТУРА}

1. Балакин Ю.В. Урало-сибирское культовое литье в мифе и ритуале. Новосибирск, 1998. - 288 с.

2. Героический эпос народа манси (вогулов): Песни святых покровителей. Ханты-Мансийск: 000 «Принт-Класс», 2010. - 648 с.

3. Головнев А.В. Говорящие культуры: традиции самодийцев и угров. Екатеринбург: Ур0 РАН, 1995. - 606 с.

4. Грачева Г.Н. Традиционные культы нганасан // Памятники культуры народов Сибири и Севера (вторая половина XIX - начало XX в.) Сб. Музея антропологии и этнографии, Т. XXXIII. - Л. Наука, 1977. С. - 217-228.

5. Земляной братец: Мансийские сказки, предания, песни, загадки / Записи, перевод, сост. и примеч. В.Н. Чернецова. - Томск; Екатеринбург: Изд-во Том. ун-та, 1997. - 136 с.: ил.

6. Источники по этнографии Западной Сибири - Томск: Изд-во Том. ун-та. 1987. - 284 с.

7. Карьялайнен К.Ф. Религия югорских народов / Пер с немец. Н.В. Лукиной. - Томск: Изд-во Том. ун-та. 1994. Т 1. - 152 с.

8. Карьялайнен К.Ф. Религия югорских народов / Пер с немец. Н.В. Лукиной. - Томск: Изд-во Том. ун-та. 1996. Т 2. - 284 с.

9. К Кулемзин В.М. Человек и природа в воззрениях хантов. Томск: Изд-во Том. ун-та. 1984б. - 192 с.

10. Кулемзин В.М., Лукина Н.В. Васюганско-ваховские ханты В конце XIX-XX начале вВ. Этнографические очерки. Томск: Изд-во Том. ун-та. 1977. - 225 с.

11. Лукина Н.В. Предисловие // Мифы, предания сказки хантов и манси» / Пер. с хантыйского, мансийского, немецкого языков, сост., предисл. и примеч. 
Н.В. Лукиной; под ред. Е.С. Новак. М: Наука, 1990. - С. 5-58.

12. Мартынова Е.П. Очерки истории и культуры хантов. М.: Институт этнологии и антропологии РАН, 1998. - 236 с.

13. Мифы, предания, сказки хантов и манси / Сост., пред. и примеч. Н.В. Лукиной. - М.: Наука, 1990. - 568 с.

14. Мифология манси / Под редакцией И.Н. Гемуева. - Новосибирск: Издательство Института археологии и этнографии СО РАН, 2001. - 196 с.

15. Молданова Т.А. Архетипы в мире сновидений хантов. Томск, 2001. - 354 с.

16. Молданов Тимофей Картина мира в песнопениях медвежьих игрищ северных ханты. Томск: Изд-во Том. ун-та. 1999. - 141 с.

17. Напольских В.В. Древние финно-угорские мифы о возникновении земли // Мировоззрение финно-угорских народов. - Новосибирск, 1990. - С. 5-21.

18. Народы Западной Сибири: Этнографический альбом / 3.П. Соколова; Ин-т этнологии и антропологии им. Н.И. Милухо-Маклая РАН. - М. : Наука, 2007. $342 \mathrm{c}$.

19. Патканов С.К. Остяцкая молитва. Сочинения в 2-х т. Т.1. Тюмень: Ю. Мандрики, 1999. - 395 с.

20. Попова С.А. Обряды перехода в традиционной культуре манси. Томск: Изд-во Том. ун-та. 2003. - 180 с.

21. Попова С.А. Мансийские календарные праздники и обряды. Томск: Изд-во Том. ун-та. 2008. - 138 с.

22. Пятникова Т.Р. Традиционные обряды хантов усть-казымского Приобья / Тамара Романовна Пятникова: Екатеринбург. - 2008. - 80 с.: ил.

23. Рыбаков Б.А. Язычество древних славян. - Москва, «Наука» 1997. - 357 с.: ил.

24. Сагалаев А.М. Урало-алтайская мифология. Символ и архетип. Новосибирск, 1991. - 155 с.

25. Семенов Ю.И. Как возникло человечество. Издательство «Наука», М., 1966. - 576 с.

26. Семенова М. Мы - славяне! СПб:, 1998. - 560 с.

27. Соколова 3.П. Уй йикв - Медвежьи игры. . . // Мифология манси. Под редакцией И.Н. Гемуева. - Новосибирск: Издательство Института археологии и этнографии СО РАН, 2001. - С. 148-149.

28. Успенская С.С. Сотворение Земли зооморфными персонажами // Мифология хантов: материалы научно-практического семинара. Ханты-Мансийск : Полиграфист, 2008. - С. 34- 49.

29. Федорова Е.Г. Историко-этнографические очерки материальной культуры манси. СПб., 1994. - 285 с.

30. Хлобыстина М.Д. Говорящие камни. Сибирские мифы и археология. Новосибирск: Издательство «Наука». 1987. - 128 с.

31. Чернецов В.Н. Фратриальное устройство обско-угорского общества // СЭ. 1939. № 11. - С. 20-43.

32. Чернецов В.Н. Медвежий праздник у обских угров / Пер. с нем. и публ. Н.В. Лукиной. - Томск: Изд-во Том. ун-та, 2001. - 48 с.

33. Шаньшина Е.В. Мифология первотворения у тунгусо-язычных народов юга Дальнего Востока России. (Опыт мифологической реконструкции и общего анализа). Владивосток, 2000. - 157 c.

34. Munkacsi B. Voqul népköltési gyütemény. I. kötet. Regék és énekek a világ teremtésérôl. Vogul szövegek és fordításaik. Bd. 3/1. Budapest: Magyar Tudományos Akadémia, $1906.593 \mathrm{~s}$. 